\title{
The Experience of Lived Time in People with Dementia: A Systematic Meta-Synthesis
}

\author{
Siren Eriksen ${ }^{a, b}$ Ruth Louise Bartlett ${ }^{c, d}$ Ellen Karine Grov ${ }^{e}$ \\ Tanja Louise Ibsen $^{a}$ Elisabeth Wiken Telenius ${ }^{a}$ Anne Marie Mork Rokstad ${ }^{a}{ }^{f}$ \\ aNorwegian National Advisory Unit on Ageing and Health, Vestfold Hospital Trust, Tønsberg, Norway; ${ }^{\text {bLovisenberg }}$ \\ Diaconal University College, Oslo, Norway; 'Faculty of Health Studies, VID Specialized University, Oslo, Norway; \\ dSchool of Health Sciences, University of Southampton, Southampton, UK; e'Department of Nursing and Health \\ Promotion, Oslo Metropolitan University, Oslo, Norway; ${ }^{\mathrm{f} F a c u l t y}$ of Health Sciences and Social Care, Molde \\ University College, Molde, Norway
}

\section{Keywords}

Dementia $\cdot$ Experience $\cdot$ Lived time $\cdot$ Meta-synthesis .

Qualitative studies

\begin{abstract}
Introduction: For people with dementia, lived time is important to understand, as the condition affects memory, perceptions of time, and life expectancy. The aim of this study was to locate, interpret, and synthesize the experience of lived time for people with dementia. Method: This article presents a qualitative systematic meta-synthesis. The theoretical framework of lifeworlds by van Manen provided the context for the study. The Critical Appraisal Skills Programme criteria for qualitative studies were used to appraise the studies. Sixty-one qualitative research studies based on interviews with people with dementia were included in the review. The analysis followed the principles of interpretive synthesis. Results: Four categories were revealed: (1) rooted in the past - "I am the same as before"; (2) focussing on the present - "Nobody has tomorrow"; (3) thinking about the future - "What is going to happen to me?"; and (4) changes in the experience of self over time - "I used to...." The latent overall meaning was expressed as "being engaged with the
\end{abstract}

karger@karger.com www.karger.com/dem

Karger $\stackrel{\text { ' }}{5}$

BOPEN ACCESS
(C) 2020 The Author(s)

Published by S. Karger AG, Basel

This article is licensed under the Creative Commons AttributionNonCommercial-NoDerivatives 4.0 International License (CC BY NC-ND) (http://www.karger.com/Services/OpenAccessLicense) Usage and distribution for commercial purposes as well as any distribution of modified material requires written permission. dimensions of time." Discussion/Conclusion: The experience of lived time is an active and important one, enabling people to manage the dementia journey. Future work involving people with dementia should foreground the experience of lived time.

(C) 2020 The Author(s)

Published by S. Karger AG, Basel

\section{Introduction}

Living with a chronic condition such as dementia creates new relations to time [1], not least because the condition is progressive and life-limiting; recent research suggests that the average life expectancy on being diagnosed with Alzheimer's disease, the most common form of dementia, is 5.7 years, but it can range from 1.9 to 6.3 years [2]. A diagnosis of dementia shortens life. Moreover, it imposes a new temporality in a person's life course. Medical texts often classify this in terms of "mild or early stage" (2-4 years), "moderate or middle stage" (2-10 years), and "severe or late stage" (1-3 years) [3] However, the idea of a linear-stage model with average timeframes is problematic; it is too deterministic and fails to take account of the care environment [4]. Critically, from our 
perspective, it overshadows the understanding of people's experiences of lived time, which are likely to vary and change during the course of the condition.

Time is typically associated with the clock, but Adams [5] and others identified another alternative to clock time, namely, temporality. Temporality is a quality that is first and foremost lived by each human being [6]. Consider, for example, how time tends to slow down when you are bored and speed up when you are enjoying yourself [7]. Temporality thus refers "to the nature or structure of time in terms of its objective existence, its subjective experience, or both and particularly with respect to the relations among its dimensions (past, present, and future) and the way in which it passes" [8]. Therefore, understanding the lived experience of time is understanding a critical aspect of human social life.

The Dutch philosopher Max van Manen [7] described lived time as 1 of 4 existential attributes that he believed were important to analyze when seeking to understand a person's life world. These 4 attributes are (1) lived body, (2) lived others, (3) lived space, and (4) lived time. He conceptualized lived time as subjective time as opposed to clock time and as a category for inquiring into the ways people experience the temporal dimensions of their life. Thus, lived time, as conceptualized in this review, is more than people's orientation to clock time; it is also related to perceptions of time and how these might change and evolve over the course of the illness.

For people with dementia, lived time is a particularly important attribute to understand, for several reasons. First, the disease process affects the hippocampus, the "core temporal device in the brain," and so perceptions of time, impairing one's "internal clock" [9]. This can cause practical problems, for example, someone getting up in the middle of night to have breakfast. Hence, there has been considerable work in dementia studies on assistive aids to help with time orientation [10].

Second, memory is one of the cognitive capacities most affected by dementia, so people with this condition often have difficulties with recalling past events and the chronological order of their life. This can create, amongst other things, a significant moral dilemma for professionals who have to make best interest decisions for someone with advanced dementia, that is, deciding what is in someone's best interests when their desires change preand post-dementia because the person no longer remembers what he/she liked and disliked [6]. Third, many people with dementia are likely to find themselves in places ruled by the clock, such as day care centres, hospitals, clinics, and care homes; even people in their own home may find their lives governed by clock time, as home care workers have to work under strict time pressures [11]. In such situations, people with dementia are likely to feel rushed and to experience time very differently to those who provide the care service [12].

A fourth and final reason for advancing understanding of the lived experience of time for people with dementia is because dementia is a chronic condition strongly associated with a particular time in the life course, namely, "old age." Consequently, those affected mid-life and diagnosed with so-called "early-onset dementia" can feel "out of time" as if things are not happening in the expected chronological order, thereby disrupting the "social clock" of one's life trajectory [13]. Analyzing how different people with dementia conceptualize and perceive of time could therefore shed fresh light on the non-linear and temporally disruptive aspects of this condition.

Understanding how people with dementia might experience lived time is important not only for the enhancement of care and time orientation but also for the development of sociological understandings of temporality in the context of chronic illness. In one of the few empirical studies that explicitly sought to understand perceptions of time among people with dementia, the main temporal problems participants had were "knowing when" and "knowing how long" [14]. In this study, "time was experienced, by the 5 participants, as something internalized, well known, and self-evident, as internal and external rhythms, giving structure and tempo to their daily lives." Other researchers have collated a collection of writings on the personal meanings of time for people with dementia and those who provide care [15]. This work reinforces what many empirical studies have concluded, namely, that people with dementia are capable of evolving into new and different selves over time [16-18]. All of this emphasizes the significance of investigating dementia temporalities.

Social science literature on the experiences of lived time for people with dementia is limited, possibly because those without dementia do not realize how important temporal experiences are to those living with the condition. In recent work on social health and dementia involving a team of professional academics and clinicians, it was not until the team sought feedback from people with dementia that the concept of time was given consideration. As the researchers note, a recurring topic in their feedback was the importance of time and how the idea of change over time should be given more attention [19]. Given how important the experience of lived time clearly is to people with dementia, there is a need for a system- 
Table 1. Search terms

\begin{tabular}{|c|c|}
\hline Dementia & Experience \\
\hline $\begin{array}{l}\text { Embase } \\
\text { (Dementia OR dementia, presenile OR dementia, senile OR } \\
\text { Alzheimer's disease OR dementia, multi-infarct OR Lewy body disease } \\
\text { OR dementia, vascular OR dementia, frontotemporal) Keyword (KW) } \\
\text { OR (dement* OR presenile dement* OR senile dement* OR } \\
\text { Alzheimer* OR multi-infarct dement* OR Lewy body dement* OR } \\
\text { vascular dement* OR frontotemporal dement*) TW } \\
\text { MEDLINE } \\
\text { (Dementia OR dementia, presenile OR dementia, senile OR } \\
\text { Alzheimer's disease OR dementia, multi-infarct OR Lewy body disease } \\
\text { OR dementia, vascular) MESH } \\
\text { OR (dement* OR presenile dement* OR senile dement* OR } \\
\text { Alzheimer* OR multi-infarct dement* OR Lewy body dement* OR } \\
\text { vascular dement* OR frontotemporal dement*) TW } \\
\text { CINAHL } \\
\text { (Dementia OR dementia, presenile OR dementia, senile OR } \\
\text { Alzheimer's disease OR dementia, multi-infarct OR Lewy body disease } \\
\text { OR dementia, vascular) MESH } \\
\text { OR (dement* OR presenile dement* OR senile dement* OR } \\
\text { Alzheimer* OR multi-infarct dement* OR Lewy body dement* OR } \\
\text { vascular dement* OR frontotemporal dement*) TX (all text) } \\
\text { PsycINFO } \\
\text { (Dementia OR dementia, presenile OR dementia, senile OR } \\
\text { Alzheimer's disease OR dementia, multi-infarct OR Lewy body disease } \\
\text { OR dementia, vascular) MESH } \\
\text { OR (dement* OR presenile dement* OR senile dement* OR } \\
\text { Alzheimer* OR multi-infarct dement* OR Lewy body dement* OR } \\
\text { vascular dement* OR frontotemporal dement*) TW } \\
\text { AGELINE } \\
\text { Dement* OR presenile dement* OR senile dement* OR Alzheimer* } \\
\text { OR multi-infarct dement* OR Lewy body dement* OR vascular } \\
\text { dement* OR frontotemporal dement*) TX (all text) } \\
\text { OR (dementia OR Alzheimer's disease OR Alzheimer's* OR Lewy } \\
\text { body**) SU (subject) }\end{array}$ & $\begin{array}{l}\text { Embase } \\
\text { (Personal experience* OR experience* OR lived experience* } \\
\text { OR life experience* OR patient experience* OR subjective } \\
\text { experience* OR first-person) TW } \\
\text { MEDLINE } \\
\text { AND (personal experience* OR experience* OR lived } \\
\text { experience* OR life experience* OR patient experience* } \\
\text { OR subjective experience* OR first-person) TW } \\
\text { CINAHL } \\
\text { (Life N1 experience) OR (personal experience* OR } \\
\text { experience* OR lived experience* OR life experience* } \\
\text { OR patient experience* OR subjective experience* } \\
\text { OR first-person) TX } \\
\text { PsycINFO } \\
\text { (Life experience) mesh OR (personal experience* OR } \\
\text { experience* OR lived experience* OR life experience* } \\
\text { OR patient experience* OR subjective experience* } \\
\text { OR first-person) TW } \\
\text { AGELINE } \\
\text { (Personal experience* OR experience* OR lived experience* } \\
\text { OR life experience* OR patient experience* OR subjective } \\
\text { experience* OR first-person) TX } \\
\text { AND (nursing methodologies OR case study OR constant } \\
\text { comparison OR content analysis OR descriptive study OR } \\
\text { discourse analysis OR ethnography OR exploratory OR } \\
\text { feminist OR grounded theory OR hermeneutic OR interview } \\
\text { OR narrative OR naturalistic OR participant observation OR } \\
\text { phenomenology OR qualitative research OR qualitative } \\
\text { methods OR qualitative study) }\end{array}$ \\
\hline
\end{tabular}

atic review that synthesizes the knowledge on this topic. Thus, the aim of this systematic synthesis was to locate, interpret, and synthesize the experience of lived time for people with dementia.

\section{Methods}

We performed the same methodological approach as for 2 previous published articles in this set of articles based on the theoretical framework by van Manen [20,21]. By a systematic literature search combining terms with a variety of combinations of dementia and experience, we screened 5 databases: AgeLine, CINAHL Complete, Embase, MEDLINE, and PsycINFO. The complete search strategy is shown in Table 1.

The Experience of Lived Time in People with Dementia
We included peer-reviewed qualitative research studies published in English between January 2004 and February 2020. We identified 7,840 articles, and 200 articles were read in full text. Further details on selection criteria are described in the flowchart shown in Figure 1.

To ensure rigour and quality, we performed a paired screening, that is, 2 authors read the articles in full text and came to consensus for further inclusion. Potential pair disagreements were to be discussed with the whole author team. Articles were included if the sample comprised people with dementia, the data were collected from qualitative interviews, and the article contained quotes or statements relating to the concept of "time." In cases of focus groups or dyad interviews were spouses or health care personnel were present during the interviews, the article had to describe the people with dementia's voice explicitly. We excluded articles that (a) had a mixed sample including both people with dementia and people with other diagnosis, (b) had a sample of people with an unclear, probable, or possible dementia diagnosis, and (c) described 
Fig. 1. Flowchart of literature search.

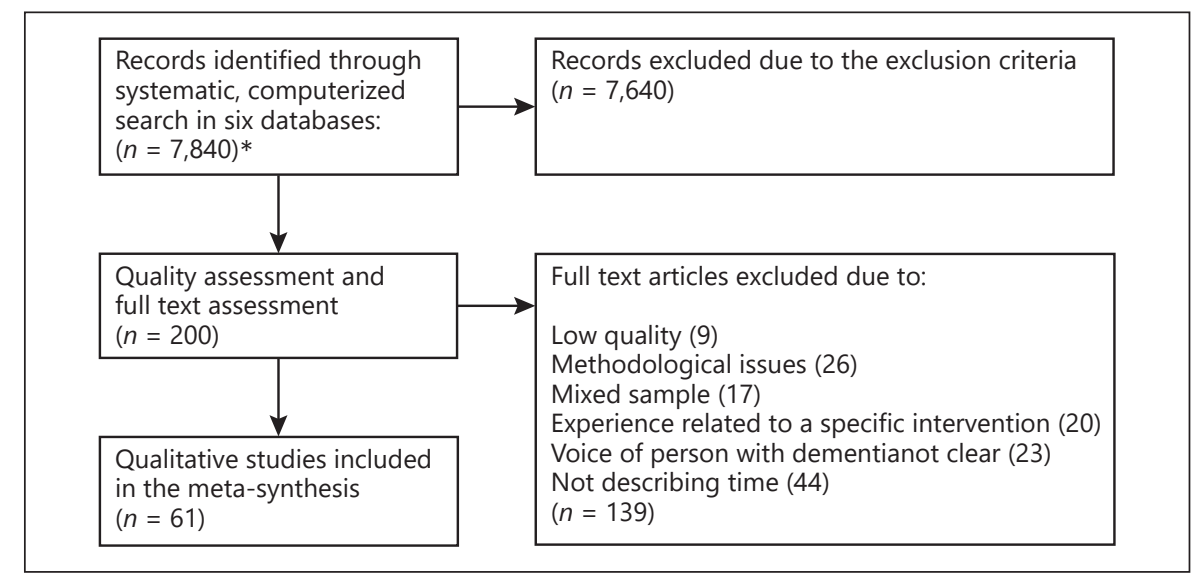

experiences that were based on an intervention and (d) were based on single cases. The quality process described here is in line with the PRISMA guidelines [22].

\section{Quality Assessment of the Studies}

A total of 69 articles were reviewed in accord with the Critical Appraisal Skills Programme (CASP) criteria for qualitative studies [23]. All the included articles were assessed according to the CASP criteria by 2 authors. Any disagreements were to be discussed with the other authors to reach consensus. Nine criteria of the CASP were used in the assessment part, all given 1 point if satisfactory stated: (1) a clear statement of aims; (2) appropriate choice of the method; (3) appropriate research design; (4) congruence between the recruitment strategy, aims, and research; (5) the data collection method addresses the research issue; (6) a relationship between the researcher and the participant was considered; (7) ethical issues were considered; (8) the process of data analysis was sufficiently rigorous; and (9) a clear statement of the findings. By such, the maximum score was 9 for each article, leaving the top score with the value of high methodological quality, while the score of 7-8 points gave a value of moderate quality. Only studies valued to moderate or high quality were included, as shown in Table 2. As a consequence of this quality assessment, 9 studies were excluded due to low quality, that is, values below 7 .

This meta-synthesis incorporates 61 articles where 762 people with dementia represent the total sample, as shown in Table 3. Thirteen of the articles reported the persons' stage of dementia or description of their cognitive function, and 27 articles described the type of dementia. Fifty-one studies served with information about the participants' living conditions and care facilities, 32 studies explicitly described that the participants lived in own homes, and 12 studies included people living in nursing homes or other care facilities. Data were obtained mostly from individual interviews (51 studies). Eight studies drew data from interviews with people with dementia, their dyads or pairs, and in 2 of the individual interviews, a caregiver was present. Five studies based their data from focus group interviews. Most studies were cross-sectional with one single interview; however, 18 studies conducted repeated interviews; of those, 2 studies carried out interviews over $>1$ year.

Data Abstraction and Meta-Synthesis

For this meta-synthesis, the data abstraction was conducted in line with the principles of an interpretative synthesis [85]. The ini- tial procedure was to create concepts from the data gathered from primary studies. Further, we gave attention to specific theories that integrated the concepts [86]. We were inspired by qualitative content analyses [87]. This particular analytic process comprised 5 steps: in the first step, pairs of authors (S.E., T.L.I., and E.K.G.) read all the included articles and extracted text that described "time." The extracted text constituted the "meaning units," a form created for further analysis. The second step incorporated condensation of meaning units (A.M.M.R. and S.E.), where the content of the direct citation was extracted using the meaning unit's own language, as shown in Table 4. Next, we labelled the condensed meaning units with codes to organize the material (A.M.M.R., R.B., and S.E.). In the third step, the codes were compared and gathered into 4 preliminary groups of categories (S.E. and E.K.G.). In the fourth step, 2 authors (A.M.M.R. and R.B.) further identified similarities and differences to make a structure, thereby gathering the codes into subcategories and 4 categories that presented the manifest meaning from the analysis. The categories were discussed by all the authors. The fifth step gave a comprehensive understanding of what we summarized and reflected upon from the findings consisting of "time" to give a description of the content as one overall latent theme (all authors) [87].

\section{Findings}

The analysis revealed 4 categories, as presented in $\mathrm{Ta}$ ble 4: (1) rooted in the past - "I am the same as before"; (2) focussing on the present - "Nobody has tomorrow"; (3) thinking about the future - "What is going to happen to me?"; and (4) changes in the experience of self over time - "I used to...."

\section{Rooted in the Past - "I Am the Same as before"}

People with dementia will often lean towards the past to make sense of their current situation. Rooting themselves in the past by looking back and reliving events seems to make it easier to accept their life situation and compensate 
Table 2. Quality assessment of studies included [24-84]

\begin{tabular}{|c|c|c|c|c|c|c|c|c|c|c|c|}
\hline \multirow[t]{2}{*}{ First author [ref.] } & \multicolumn{9}{|c|}{ Criteria* } & \multirow[t]{2}{*}{ Total/9 } & \multirow[t]{2}{*}{ Quality } \\
\hline & 1 & 2 & 3 & 4 & 5 & 6 & 7 & 8 & 9 & & \\
\hline Aldridge et al. [24] & + & + & + & + & + & - & + & + & + & 8 & Moderate \\
\hline Aminzadeh et al. [25] & + & + & + & + & + & - & + & + & + & 8 & Moderate \\
\hline Atta-Konadu et al. [26] & + & + & + & + & + & - & - & + & + & 7 & Moderate \\
\hline Barrett et al. [27] & + & + & + & - & +- & - & + & + & + & 7 & Moderate \\
\hline Beattie et al. [28] & + & + & + & + & + & - & + & + & + & 8 & Moderate \\
\hline Borley and Hardy [29] & + & + & + & + & + & - & + & + & + & 8 & Moderate \\
\hline Bronner et al. [30] & + & + & + & + & + & - & - & + & + & 7 & Moderate \\
\hline Brorsson et al. [31] & + & + & + & + & + & - & + & + & + & 8 & Moderate \\
\hline Chaplin and Davidson [32] & + & + & + & + & + & - & + & + & + & 8 & Moderate \\
\hline Clare et al. [33] & + & + & + & + & + & - & + & + & + & 8 & Moderate \\
\hline Clemerson et al. [34] & + & + & + & + & + & - & + & + & + & 8 & Moderate \\
\hline Dalby et al. [35] & + & + & + & + & + & + & + & + & + & 9 & High \\
\hline Derksen et al. [36] & + & + & + & + & + & - & + & + & + & 8 & Moderate \\
\hline De Witt et al. [37] & + & + & + & + & + & - & + & + & + & 8 & Moderate \\
\hline De Witt et al. [38] & + & + & + & + & + & - & + & + & + & 8 & Moderate \\
\hline Digby et al. [39] & + & + & + & + & + & + & + & - & + & 8 & Moderate \\
\hline Frazer et al. [40] & + & + & + & + & + & - & + & + & + & 8 & Moderate \\
\hline Genoe et al. [41] & + & + & + & + & + & - & + & + & + & 8 & Moderate \\
\hline Genoe et al. [42] & + & + & + & + & + & - & + & + & + & 8 & Moderate \\
\hline Genoe and Dupuis [43] & + & + & + & + & + & + & + & + & + & 9 & High \\
\hline Gilmour and Huntington [44] & + & + & + & + & + & - & + & + & + & 8 & Moderate \\
\hline Goodman et al. [45] & + & + & + & + & + & - & + & + & + & 8 & Moderate \\
\hline Hagan [46] & + & + & + & + & + & + & + & + & + & 9 & High \\
\hline Harman and Clare [47] & + & + & + & + & + & + & + & + & + & 9 & High \\
\hline Harmer and Orrell [48] & + & + & + & + & + & - & + & + & + & 8 & Moderate \\
\hline Hedman et al. [49] & + & + & + & + & + & - & + & + & + & 8 & Moderate \\
\hline Hedman et al. [50] & + & + & + & + & + & + & + & + & + & 9 & High \\
\hline Hellström et al. [51] & + & + & + & + & + & - & + & + & + & 8 & Moderate \\
\hline Hillman et al. [52] & + & + & + & - & + & - & + & + & + & 7 & Moderate \\
\hline Hulko [53] & + & + & + & + & + & - & + & + & + & 8 & Moderate \\
\hline Johannessen et al. [54] & + & + & + & + & +- & - & + & + & + & 8 & Moderate \\
\hline Johannessen et al. [55] & +++ & + & + & + & + & & + & + & + & 8 & Moderate \\
\hline Karlsson et al. [56] & + & + & + & + & + & - & + & + & + & 8 & Moderate \\
\hline Keller et al. [57] & + & + & + & + & + & + & - & + & + & 8 & Moderate \\
\hline Langdon et al. [58] & + & + & + & + & + & + & + & + & + & 9 & High \\
\hline Lee et al. [59] & + & + & + & + & + & - & + & - & + & 7 & Moderate \\
\hline MacKinley [60] & + & + & + & + & + & - & + & + & + & 8 & Moderate \\
\hline MacRae [61] & + & + & + & + & + & + & + & + & + & 9 & High \\
\hline Mazaheri et al. [62] & + & + & + & + & + & + & + & + & + & 9 & High \\
\hline Merrick et al. [63] & + & + & + & + & + & - & - & + & + & 7 & Moderate \\
\hline Mjorud et al. [64] & + & + & + & + & + & - & + & + & + & 8 & Moderate \\
\hline Mok et al. [65] & + & + & + & + & + & - & + & + & + & 8 & Moderate \\
\hline Moyle et al. [66] & + & + & + & + & + & - & + & + & + & 8 & Moderate \\
\hline Molyneaux et al. [67] & + & + & + & + & + & + & + & + & + & 9 & High \\
\hline Nowell et al. [68] & + & + & + & + & + & + & + & + & + & 9 & High \\
\hline Nygård [69] & + & + & + & + & + & - & - & + & + & 7 & Moderate \\
\hline Pesonen et al. [70] & + & + & + & + & + & - & + & + & + & 8 & Moderate \\
\hline Pipon-Young et al. [71] & + & + & + & + & + & - & + & + & + & 8 & Moderate \\
\hline Read et al. [72] & + & + & + & + & + & - & + & + & + & 8 & Moderate \\
\hline Rostad et al. [73] & + & + & + & + & + & - & + & + & + & 8 & Moderate \\
\hline Sharp [74] & + & + & + & + & + & - & + & + & + & 8 & Moderate \\
\hline Sinclair et al. [75] & + & + & + & + & + & - & + & + & + & 8 & Moderate \\
\hline Sinclair et al. [76] & + & + & + & + & + & + & + & + & + & 9 & High \\
\hline Stevenson et al. [77] & + & + & + & + & + & + & + & + & + & 9 & High \\
\hline Svanström and Sundler [78] & + & + & + & + & + & - & + & + & + & 8 & Moderate \\
\hline Tolhurst and Weicht [79] & + & + & + & + & + & + & + & + & + & 9 & High \\
\hline Van Vliet et al. [80] & + & + & + & + & + & - & + & + & + & 8 & Moderate \\
\hline Van Zadelhoff et al. [81] & + & + & + & + & + & - & + & + & + & 8 & Moderate \\
\hline Willis et al. [82] & + & + & + & + & + & - & + & + & + & 8 & Moderate \\
\hline Wolverson et al. [83] & + & + & + & + & + & - & - & + & + & 7 & Moderate \\
\hline Öhman and Nygård [84] & + & + & + & + & + & - & - & + & + & 7 & Moderate \\
\hline
\end{tabular}

* CASP criteria: (1) clear research statement; (2) qualitative methodology; (3) research question appropriate; (4) recruitment strategy; (5) data collection; (6) relationship between the researcher and the participant described adequately; (7) ethical considerations; (8) data analysis; (9) clear statements of findings. Scores: 9, high quality; 7-8, moderate quality; 6 or less, low quality. 
Table 3. Presentation of studies included

\begin{tabular}{|c|c|c|c|}
\hline Authors [ref.] & Aim & Participants & Method \\
\hline $\begin{array}{l}\text { Aldridge } \\
\text { et al. [24] }\end{array}$ & $\begin{array}{l}\text { To expand on this limited understanding } \\
\text { and gain a deeper insight as to how shame is } \\
\text { experienced and made sense of by people } \\
\text { with early-stage dementia by exploring this } \\
\text { topic directly with the people themselves }\end{array}$ & $\begin{array}{l}N=5 \text { persons with dementia } \\
\mathrm{AD}(3) \text {, vascular }(1) \text {, and } \\
\text { mixed/vascular (2) } \\
\text { Diagnosis of dementia } 2-6 \text { months } \\
\text { prior to interview } \\
\text { Age: } 74-90 \text { years } \\
\text { Women: } 33 \% \\
\text { UK }\end{array}$ & $\begin{array}{l}\text { Semi-structured interview in own home. } \\
\text { Analysis of interviews was based upon the IPA } \\
\text { procedure outlined by Smith and Yardley }\end{array}$ \\
\hline $\begin{array}{l}\text { Aminzadeh } \\
\text { et al. [25] }\end{array}$ & $\begin{array}{l}\text { To explore the subjective meaning of } \\
\text { relocation for people with dementia moving } \\
\text { into residential care }\end{array}$ & $\begin{array}{l}N=16 \text { persons with dementia living at } \\
\text { home and planning to move to } \\
\text { residential care within } 2 \text { months } \\
\text { Canada }\end{array}$ & $\begin{array}{l}\text { Individual in-depth interviews } \\
\text { Field notes as supplementary data } \\
\text { Analyses were guided by the work of Corbin } \\
\text { and Strauss }\end{array}$ \\
\hline $\begin{array}{l}\text { Atta-Konadu } \\
\text { et al. [26] }\end{array}$ & $\begin{array}{l}\text { To provide a broader perspective and } \\
\text { insight into the food-related role shift } \\
\text { experiences of husbands and their wives } \\
\text { with dementia by presenting the accounts of } \\
\text { both spouses in the couple }\end{array}$ & $\begin{array}{l}N=9 \text { persons with dementia living at } \\
\text { home and their spousal care partners } \\
\text { Age range: } 58-86 \text { years } \\
\text { Women: } 100 \% \\
\text { Living with partner: } 100 \% \\
\text { Canada }\end{array}$ & $\begin{array}{l}\text { Participants were interviewed yearly over a } \\
3 \text {-year period (the last year only } 5 \text { husbands } \\
\text { and wives were still involved). First couples } \\
\text { interviewed in dyads, and then individual } \\
\text { interviews were accomplished } 1 \text { week to } 1 \\
\text { month later } \\
\text { Data were analyzed using the constant } \\
\text { comparative method described by Corbin and } \\
\text { Strauss }\end{array}$ \\
\hline $\begin{array}{l}\text { Barrett } \\
\text { et al. [27] }\end{array}$ & $\begin{array}{l}\text { To outline the experiences and needs of } \\
\text { lesbian, gay, bisexual, and trans Australians } \\
\text { with dementia - and their partners }\end{array}$ & $\begin{array}{l}N=9 \text { persons with dementia, partners } \\
(21) \text { and service providers } \\
\text { Age range: } 47-79 \text { years } \\
\text { Australia }\end{array}$ & $\begin{array}{l}\text { In-depth interviews mostly face to face }(20) \\
\text { were conducted. Data were analyzed using } \\
\text { qualitative data analysis for applied policy } \\
\text { research in line with Ritchie and Spencer }\end{array}$ \\
\hline $\begin{array}{l}\text { Beattie } \\
\text { et al. [28] }\end{array}$ & $\begin{array}{l}\text { To demonstrate how interviews can be } \\
\text { conducted with younger people with } \\
\text { dementia }\end{array}$ & $\begin{array}{l}N=14 \text { participants who had received a } \\
\text { diagnosis of dementia and were using } \\
\text { services } \\
\text { UK }\end{array}$ & $\begin{array}{l}\text { Semi-structured, individual in-depth interviews } \\
\text { Data were transcribed and subjected to } \\
\text { comparative textual analysis guided by the } \\
\text { principles of Strauss and Corbin }\end{array}$ \\
\hline $\begin{array}{l}\text { Bronner } \\
\text { et al. [30] }\end{array}$ & $\begin{array}{l}\text { To identify medical and social topics which } \\
\text { become relevant in the period following } \\
\text { diagnosis of } \mathrm{AD} \text {, for which a decision may } \\
\text { eventually need to be made and which has } \\
\text { implications for the life and wellbeing of the } \\
\text { persons with } \mathrm{AD}\end{array}$ & $\begin{array}{l}N=5 \text { persons with } \mathrm{AD} \text {, relatives }(6), \\
\text { and professionals }(13) \\
\text { Germany }\end{array}$ & $\begin{array}{l}\text { Semi-structured face-to-face interviews } \\
\text { Data were analyzed using content analysis in } \\
\text { accordance with Mayring }\end{array}$ \\
\hline $\begin{array}{l}\text { Brorsson } \\
\text { et al. [31] }\end{array}$ & $\begin{array}{l}\text { To illuminate experiences of accessibility in } \\
\text { public space in people with } \mathrm{AD} \text {, with } \\
\text { particular focus on place, situations, and } \\
\text { activities that they found to be important for } \\
\text { daily life }\end{array}$ & $\begin{array}{l}N=7 \text { persons diagnosed with early } \mathrm{AD}, \\
\text { living at home } \\
\text { Sweden }\end{array}$ & $\begin{array}{l}\text { Repeated in-depth interviews. All, except for } \\
\text { one informant, were interviewed twice } \\
\text { Data were analyzed using open coding in } \\
\text { accord with Corbin and Strauss }\end{array}$ \\
\hline $\begin{array}{l}\text { Chaplin and } \\
\text { Davidson } \\
{[32]}\end{array}$ & $\begin{array}{l}\text { To focus specially on the experiences of } \\
\text { people developing a dementia while still in } \\
\text { employment in the UK }\end{array}$ & $\begin{array}{l}N=5 \text { persons with AD still being } \\
\text { employed } \\
\text { MMSE score range: } 25-28 \\
\text { Age range: } 58-74 \text { years } \\
\text { Women: } 20 \% \\
\text { UK }\end{array}$ & $\begin{array}{l}\text { Individual semi-structured interviews on a } \\
\text { single occasion. Data were analyzed using } \\
\text { interpretative phenomenological analysis }\end{array}$ \\
\hline
\end{tabular}


Table 3 (continued)

\begin{tabular}{llll}
\hline Authors [ref.] & Aim & Participants & Method \\
\hline $\begin{array}{llll}\text { Clare } \\
\text { et al. [33] }\end{array}$ & $\begin{array}{l}\text { To explore the subjective experience of with } \\
\text { dementia in residential care and to } \\
\text { understand the psychological impact of } \\
\text { being in this situation }\end{array}$ & $\begin{array}{l}N=81 \text { persons with dementia living in } \\
\text { residential care homes }\end{array}$ & $\begin{array}{l}\text { An existing dataset consisting of individual } \\
\text { unstructured conversations with people } \\
\text { with dementia from a study of wellbeing in } \\
\text { residential care was used. The number of } \\
\text { conversations recorded with each participant } \\
\text { ranged from 1 to 8. The total dataset consisted } \\
\text { of 304 transcripts } \\
\text { Interpretative phenomenological analysis as } \\
\text { guiding design }\end{array}$ \\
\end{tabular}

\begin{tabular}{lll}
\hline Clemerson & To explore the individuals' subjective & N=8 persons with AD living at home \\
et al. [34] & experiences of young-onset dementia & MMSE score range: $17-21$ \\
& & Age range: $35-60$ years \\
& Women: $12.5 \%$ \\
& Living with someone (partner or others): \\
& $75.0 \%$ \\
& UK
\end{tabular}

Individual semi-structured interviews were performed

Data were analyzed using interpretative phenomenological analysis

UK

\begin{tabular}{|c|c|c|c|}
\hline $\begin{array}{l}\text { Dalby } \\
\text { et al. [35] }\end{array}$ & $\begin{array}{l}\text { To understand the experience of spirituality } \\
\text { in the context of living with dementia. In } \\
\text { addition, a second aim was to understand } \\
\text { the experience of dementia in the context of } \\
\text { spiritual belief }\end{array}$ & $\begin{array}{l}N=6 \text { persons with dementia living at } \\
\text { home }(75 \%) \text {, in assisted living }(12.5 \%) \text {, } \\
\text { or in nursing home }(12.5 \%) \\
\text { Age range: from } 70 \text { s to } 90 \mathrm{~s} \\
\text { Women: } 83.3 \% \\
\text { Living with partner: } 16.7 \% \\
\text { UK }\end{array}$ & $\begin{array}{l}\text { Individual semi-structured interviews with } \\
\text { participants were performed } \\
\text { Data were analyzed using interpretative } \\
\text { phenomenological analysis }\end{array}$ \\
\hline $\begin{array}{l}\text { Derksen } \\
\text { et al. [36] }\end{array}$ & $\begin{array}{l}\text { To describe and appraise the experiences, } \\
\text { beliefs, and fears regarding the diagnosis of } \\
\text { dementia in both patients and carers }\end{array}$ & $\begin{array}{l}N=18 \text { persons with dementia and their } \\
\text { family carers } \\
\text { Mean MMSE score: } 22 \text { (range: } 15-30 \text { ) } \\
\text { Mean age: } 71 \text { years } \\
\text { Women: } 20 \% \\
\text { Living with partner } 85 \% \\
\text { The Netherlands }\end{array}$ & $\begin{array}{l}\text { Individual semi-structured interviews with } \\
\text { patient and the carers were performed } \\
\text { separately. Two interviews with participants; } \\
\text { the first } 2 \text { weeks after the diagnostic disclosure } \\
\text { and } 10 \text { weeks later } \\
\text { Data were analysed using the constant } \\
\text { comparative method in line with Corbin and } \\
\text { Strauss }\end{array}$ \\
\hline $\begin{array}{l}\text { De Witt } \\
\text { et al. [37] }\end{array}$ & $\begin{array}{l}\text { To understand the meaning of living alone } \\
\text { for older people with dementia }\end{array}$ & $\begin{array}{l}N=8 \text { women diagnosed with mild-to- } \\
\text { moderate AD or related dementia living } \\
\text { alone in the community } \\
\text { Canada }\end{array}$ & $\begin{array}{l}\text { Repeated face-to-face, open-ended interviews. } \\
\text { All, except for } 2 \text { informants, were interviewed } \\
\text { twice } \\
\text { Data were analyzed using } 3 \text { techniques in } \\
\text { accord with van Manen }\end{array}$ \\
\hline $\begin{array}{l}\text { De Witt } \\
\text { et al. [38] }\end{array}$ & $\begin{array}{l}\text { To understand the meaning of living alone } \\
\text { from the perspective of older people with } \\
\text { Alzheimer disease or a related dementia }\end{array}$ & $\begin{array}{l}N=8 \text { women diagnosed with mild-to- } \\
\text { moderate AD or related dementia living } \\
\text { alone in the community } \\
\text { Canada }\end{array}$ & $\begin{array}{l}\text { Repeated face-to-face, open-ended interviews. } \\
\text { All, except for } 2 \text { informants, were interviewed } \\
\text { twice } \\
\text { Data were analyzed using } 3 \text { techniques in } \\
\text { accord with van Manen }\end{array}$ \\
\hline $\begin{array}{l}\text { Digby } \\
\text { et al. [39] }\end{array}$ & $\begin{array}{l}\text { To understand how older patients with } \\
\text { mild-to-moderate dementia experienced the } \\
\text { transfer from acute to sub-acute care and } \\
\text { settling-in period }\end{array}$ & $\begin{array}{l}N=8 \text { persons with dementia staying in } \\
\text { a sub-acute facility } \\
\text { Australia }\end{array}$ & $\begin{array}{l}\text { In-depth semi-structured interviews using the } \\
\text { communication techniques recommended by } \\
\text { Young and Manthorp. Data were analyzed } \\
\text { using content analysis in accord with Hsieh and } \\
\text { Shannon }\end{array}$ \\
\hline $\begin{array}{l}\text { Frazer } \\
\text { et al. [40] }\end{array}$ & $\begin{array}{l}\text { To explore how women who live alone with } \\
\text { dementia see themselves and how they cope } \\
\text { in their everyday lives }\end{array}$ & $\begin{array}{l}N=8 \text { persons with dementia }(\mathrm{AD}=5) \\
\text { living at home } \\
\text { UK }\end{array}$ & $\begin{array}{l}\text { Individual, semi-structured interviews were } \\
\text { performed } \\
\text { Data were analyzed using the interpretative } \\
\text { phenomenological approach }\end{array}$ \\
\hline
\end{tabular}


Table 3 (continued)

\begin{tabular}{|c|c|c|c|}
\hline Authors [ref.] & Aim & Participants & Method \\
\hline $\begin{array}{l}\text { Genoe } \\
\text { et al. [41] }\end{array}$ & $\begin{array}{l}\text { To explore the experience and meaning of } \\
\text { food and mealtimes for people with } \\
\text { dementia and their primary partners in care }\end{array}$ & $\begin{array}{l}N=27 \text { persons with dementia }(\mathrm{AD}=25) \\
\text { living at home together with their } \\
\text { primary family caregivers }(19 \text { spousal } \\
\text { relationships and } 8 \text { adult-child } \\
\text { relationships) } \\
\text { Majority were in early stage of dementia } \\
\text { Age range: } 56-88 \text { years } \\
\text { Women: } 59.3 \% \\
\text { Living with someone: } 100 \% \\
\text { Canada }\end{array}$ & $\begin{array}{l}\text { Dyad interviews followed by individual } \\
\text { interviews within } 2 \text { weeks were conducted. } \\
\text { Data were analyzed using grounded theory } \\
\text { approach as described by Charmaz - the } \\
\text { constant comparative method }\end{array}$ \\
\hline $\begin{array}{l}\text { Genoe } \\
\text { et al. [42] }\end{array}$ & $\begin{array}{l}\text { To explore the meaning and experience of } \\
\text { change surrounding mealtimes for people } \\
\text { with dementia living in the community and } \\
\text { their primary partners in care }\end{array}$ & $\begin{array}{l}N=27 \text { persons with dementia }(\mathrm{AD}=25) \\
\text { living at home together with their } \\
\text { primary family caregivers }(19 \text { spousal } \\
\text { relationships and } 8 \text { adult-child } \\
\text { relationships) } \\
\text { Majority were in early stage of dementia } \\
\text { Age range: } 56-88 \text { years } \\
\text { Women: } 59.3 \% \\
\text { Canada }\end{array}$ & $\begin{array}{l}\text { Dyad interviews followed by individual } \\
\text { interviews within } 2 \text { weeks were conducted } \\
\text { Data were analyzed using grounded theory } \\
\text { approach as described by Charmaz - the } \\
\text { constant comparative method }\end{array}$ \\
\hline $\begin{array}{l}\text { Genoe and } \\
\text { Dupuis [43] }\end{array}$ & $\begin{array}{l}\text { To explore how people with dementia think } \\
\text { about and describe leisure in the context of } \\
\text { their lives }\end{array}$ & $\begin{array}{l}N=4 \text { persons with early-stage dementia } \\
\text { living at home } \\
\text { Age range: } 70-82 \text { years } \\
\text { Women: } 50 \% \\
\text { Living with partner: } 50 \% \text { (both men) } \\
\text { Canada }\end{array}$ & $\begin{array}{l}\text { Individual interviews with each participant } \\
\text { were accomplished. Data were also collected } \\
\text { through participant observation and photo } \\
\text { voice } \\
\text { Data was analyzed using van Manen's } \\
\text { phenomenological reflection }\end{array}$ \\
\hline $\begin{array}{l}\text { Gilmour and } \\
\text { Huntington } \\
{[44]}\end{array}$ & $\begin{array}{l}\text { To explore the experiences of living with } \\
\text { memory loss }\end{array}$ & $\begin{array}{l}N=9 \text { persons with dementia living at } \\
\text { home } \\
\text { New Zealand }\end{array}$ & $\begin{array}{l}\text { Individual, semi-structured interviews using } \\
\text { open questions were used. To assist } \\
\text { participants, questions were provided on } \\
\text { beforehand and many participants wrote } \\
\text { reminder notes prior to the interview } \\
\text { Thematic analyses were undertaken }\end{array}$ \\
\hline $\begin{array}{l}\text { Harman and } \\
\text { Clare [47] }\end{array}$ & $\begin{array}{l}\text { To explore the experience of living with } \\
\text { dementia with focus on what makes } \\
\text { activities meaningful for people with } \\
\text { dementia }\end{array}$ & $\begin{array}{l}N=17 \text { persons with dementia living in } \\
\text { residential care homes, in addition their } \\
\text { family caregivers (8) and staff (15) } \\
\text { UK }\end{array}$ & $\begin{array}{l}\text { Focus group design with a constructed question } \\
\text { guide with residents, staff, and relatives of the } \\
\text { residents was performed. } \\
\text { Mind map notes } \\
\text { Data were analyzed using grounded theory } \\
\text { approach with content analysis }\end{array}$ \\
\hline $\begin{array}{l}\text { Harmer and } \\
\text { Orrell [48] }\end{array}$ & $\begin{array}{l}\text { To explore concepts of meaningful activity, } \\
\text { as defined by older people with dementia } \\
\text { living in care homes, staff, and family carers }\end{array}$ & $\begin{array}{l}N=17 \text { residents with dementia } \\
\text { diagnosis from } 3 \text { care homes (and } \\
15 \text { staff and } 8 \text { family carers) } \\
\text { Age: } 72-99 \text { years } \\
\text { Women: } n=12 \\
\text { UK }\end{array}$ & $\begin{array}{l}\text { Focus groups } \\
\text { Content analyses were undertaken }\end{array}$ \\
\hline $\begin{array}{l}\text { Hedman } \\
\text { et al. [49] }\end{array}$ & $\begin{array}{l}\text { To explore the use of Harré's social } \\
\text { constructionist theory of selfhood to } \\
\text { describe how people with mild-to-moderate } \\
\text { AD express their sense of self }\end{array}$ & $\begin{array}{l}N=12 \text { persons with } \mathrm{AD} \text { living at home } \\
\text { Sweden }\end{array}$ & $\begin{array}{l}\text { Individual, semi-structured interviews were } \\
\text { performed } \\
\text { Data were analyzed using phenomenological } \\
\text { approach in accord with Harrés theory of } \\
\text { social constructionist }\end{array}$ \\
\hline
\end{tabular}


Table 3 (continued)

\begin{tabular}{|c|c|c|c|}
\hline Authors [ref.] & Aim & Participants & Method \\
\hline $\begin{array}{l}\text { Hedman } \\
\text { et al. [50] }\end{array}$ & $\begin{array}{l}\text { To describe how } 5 \text { people with mild-to- } \\
\text { moderate } \mathrm{AD} \text { express their personal } \\
\text { attributes and life histories }\end{array}$ & $\begin{array}{l}N=5 \text { persons with mild-to-moderate } \\
\text { AD } \\
\text { Age range: } 59-78 \text { years } \\
\text { Women: } 60 \% \\
\text { Living with partners: } 80 \% \\
\text { Sweden }\end{array}$ & $\begin{array}{l}10 \text { support-group sessions during a 8-month } \\
\text { period } \\
\text { Data were analyzed using an abductive } \\
\text { approach in accord with McAdams and } \\
\text { Graneheim and Lundman }\end{array}$ \\
\hline Hulko [53] & $\begin{array}{l}\text { To explore the experience of older people } \\
\text { with dementia and in which way socio- } \\
\text { culture plays a role in diverse dementia } \\
\text { patients' daily living }\end{array}$ & $\begin{array}{l}N=8 \text { persons with dementia }(\mathrm{AD}=7) \\
\text { living at home and their relatives }(50) \\
\text { Canada }\end{array}$ & $\begin{array}{l}\text { Series of individual in-home interviews over } \\
1-2 \text { months and observation sessions were used } \\
\text { Data were analyzed in accord with grounded } \\
\text { theory }\end{array}$ \\
\hline $\begin{array}{l}\text { Johannessen } \\
\text { et al. [55] }\end{array}$ & $\begin{array}{l}\text { To examine how people living alone with } \\
\text { YOD perceive the course of dementia, their } \\
\text { needs, and coping strategies, with a focus on } \\
\text { narrating everyday life experiences } \\
\text { Longitudinal study over } 2 \text { years }\end{array}$ & $\begin{array}{l}N=10 \text { persons with YOD } \\
\text { frontotemporal dementia excluded } \\
\text { Age: } 49-67 \text { years } \\
\text { Women: } n=7 \\
\text { Norway }\end{array}$ & $\begin{array}{l}\text { Individual qualitative interviews. Five } \\
\text { interviews in } 2 \text { years } \\
\text { Analysis: Corbin and Strauss, a reformulated } \\
\text { approach to grounded theory }\end{array}$ \\
\hline $\begin{array}{l}\text { Karlsson } \\
\text { et al. [56] }\end{array}$ & $\begin{array}{l}\text { To explore how people with } \mathrm{AD} \text { present } \\
\text { their life story }\end{array}$ & $\begin{array}{l}N=9 \text { participants diagnosed with AD, } \\
\text { living at home } \\
\text { MMSE: } 19-25 \\
\text { Age: } 60-81 \text { years } \\
\text { Women: } 55.5 \% \\
\text { Living with spouse: } 88.9 \%(8) \\
\text { Sweden }\end{array}$ & $\begin{array}{l}\text { Individual, narrative interviews were conducted } \\
\text { Data were analyzed with the method for } \\
\text { analysis of narrative in accordance with } \\
\text { Polkinghorne }\end{array}$ \\
\hline $\begin{array}{l}\text { Keller } \\
\text { et al. [57] }\end{array}$ & $\begin{array}{l}\text { To explore the mealtimes to provide } \\
\text { opportunity for social activity and emotional } \\
\text { connection }\end{array}$ & $\begin{array}{l}N=27 \text { participants with early-to-mild } \\
\text { stage of dementia living at home and } \\
\text { their next of kin (28) } \\
\text { Canada }\end{array}$ & $\begin{array}{l}\text { Active interviews with both individual and } \\
\text { dyads were performed } \\
\text { Data were analyzed using grounded theory } \\
\text { methodology in accord with Charmaz and team } \\
\text { analysis }\end{array}$ \\
\hline
\end{tabular}


Table 3 (continued)

\begin{tabular}{|c|c|c|c|}
\hline Authors [ref.] & Aim & Participants & Method \\
\hline $\begin{array}{l}\text { Langdon } \\
\text { et al. [58] }\end{array}$ & $\begin{array}{l}\text { To explore the social effects of diagnosis of } \\
\text { dementia }\end{array}$ & $\begin{array}{l}N=12 \text { persons with dementia living at } \\
\text { home } \\
\text { MMSE range: } 19-30 \\
\text { Mean age: } 79 \text { (range: } 66-87 \text { ) years } \\
\text { Women: } 50 \% \\
\text { UK }\end{array}$ & $\begin{array}{l}\text { Individual semi-structured in-depth interviews } \\
\text { were performed } \\
\text { Data were analyzed in accord with } \\
\text { interpretative phenomenological approach }\end{array}$ \\
\hline MacRae [61] & $\begin{array}{l}\text { To examine how others' reactions to and } \\
\text { treatment of people living with early-stage } \\
\text { AD influence their experience of dementia }\end{array}$ & $\begin{array}{l}N=9 \text { persons with early stage AD living } \\
\text { at home (7), in senior's residence (1), or } \\
\text { in a convent (1) } \\
\text { Mean age: } 74 \text { years } \\
\text { Women: } 22.2 \% \\
\text { Living with partner: } 44.4 \% \\
\text { Canada }\end{array}$ & $\begin{array}{l}\text { Individual in-depth, interviews using a } \\
\text { symbolic interactionist perspective were } \\
\text { performed } \\
\text { Data were analyzed using inductive emergent } \\
\text { process in accord with Coffey and Atkinson, } \\
\text { Lofland and Lofland, and Taylor and Bogdan }\end{array}$ \\
\hline $\begin{array}{l}\text { Mazaheri } \\
\text { et al. [62] }\end{array}$ & $\begin{array}{l}\text { To describe experience of living with } \\
\text { dementia in Iran }\end{array}$ & $\begin{array}{l}N=15 \text { persons with moderate } \mathrm{AD} \text {, or } \\
\text { vascular dementia, living at home } \\
\text { Mean MMSE: } 16.5 \text { (range: } 14-19 \text { ) } \\
\text { Mean age: } 72 \text { (range } 60-87 \text { ) years } \\
\text { Women: } 40 \% \\
\text { Living with someone: } 80 \% \\
\text { Iran }\end{array}$ & $\begin{array}{l}\text { Individual semi-structured interviews were } \\
\text { performed } \\
\text { Data were analyzed using content analysis in } \\
\text { accord with Graneheim and Lundman }\end{array}$ \\
\hline $\begin{array}{l}\text { Mjorud } \\
\text { et al. [64] }\end{array}$ & $\begin{array}{l}\text { To investigate the personal experience of } \\
\text { living in a nursing home over time and what } \\
\text { makes life better or worse from the } \\
\text { perspective of the person with dementia }\end{array}$ & $\begin{array}{l}N=12 \text { persons with dementia living in } \\
\text { nursing home care units for persons } \\
\text { with dementia } \\
\text { Norway }\end{array}$ & $\begin{array}{l}\text { Repeated individual, unstructured interviews } \\
\text { were conducted } 3 \text { months apart } \\
\text { Field observations were conducted. } \\
\text { Data were analyzed using phenomenological- } \\
\text { hermeneutical analysis in accordance with } \\
\text { Lindseth and Norberg }\end{array}$ \\
\hline $\begin{array}{l}\text { Mok } \\
\text { et al. [65] }\end{array}$ & $\begin{array}{l}\text { To explore the experiences and concerns of } \\
\text { about how culture and socioecological } \\
\text { factors influence the experience among } \\
\text { Chinese with early-stage dementia }\end{array}$ & $\begin{array}{l}N=15 \text { persons with early stage dementia } \\
\text { Women: } n=11 \\
\text { Age: } 56-80 \\
\text { China }\end{array}$ & $\begin{array}{l}\text { Individual qualitative interviews with care } \\
\text { givers present } \\
\text { Data were analyzed using the Colaizzi's } \\
\text { descriptive phenomenological method }\end{array}$ \\
\hline $\begin{array}{l}\text { Moyle } \\
\text { et al. [66] }\end{array}$ & $\begin{array}{l}\text { To explore the factors that influence QOL } \\
\text { for people with dementia in LTC, including } \\
\text { an understanding of how they perceived } \\
\text { they were valued }\end{array}$ & $\begin{array}{l}N=32 \text { persons with dementia from } \\
4 \text { care homes } \\
\text { Women: } n=22 \\
\text { Australia }\end{array}$ & $\begin{array}{l}\text { In-depth interviews were conducted } \\
\text { A computer-assisted concept-mapping } \\
\text { programme was used to assist in analysis of the } \\
\text { qualitative data through rank-ordering of } \\
\text { concepts }\end{array}$ \\
\hline
\end{tabular}


Table 3 (continued)

\begin{tabular}{|c|c|c|c|}
\hline Authors [ref.] & Aim & Participants & Method \\
\hline $\begin{array}{l}\text { Molyneaux } \\
\text { et al. [67] }\end{array}$ & $\begin{array}{l}\text { To understand "couple-hood" as it is } \\
\text { co-constructed by the couple } \\
\text { when } 1 \text { partner has dementia }\end{array}$ & $\begin{array}{l}N=5 \text { persons with } \mathrm{AD} \text { and their partner } \\
\text { living at home } \\
\text { UK }\end{array}$ & $\begin{array}{l}\text { The couples were interviewed simultaneously } \\
\text { Data were analyzed using constructivist } \\
\text { grounded theory approach in accord with } \\
\text { Charmaz }\end{array}$ \\
\hline $\begin{array}{l}\text { Nowell } \\
\text { et al. [68] }\end{array}$ & $\begin{array}{l}\text { To understand personhood by exploring the } \\
\text { subjective experiences of those with } \\
\text { dementia in UK }\end{array}$ & $\begin{array}{l}N=7 \text { persons with dementia living in } \\
\text { dementia care units } \\
\text { UK }\end{array}$ & $\begin{array}{l}\text { Individual semi-structured individual } \\
\text { interviews were performed } \\
\text { Data were analyzed using an interpretative } \\
\text { phenomenological approach }\end{array}$ \\
\hline Nygård [69] & $\begin{array}{l}\text { To explore how people with dementia who } \\
\text { live alone experienced the meaning of their } \\
\text { everyday technology, such as telephone and } \\
\text { electronic equipment and the use of it }\end{array}$ & $\begin{array}{l}N=8 \text { persons with dementia living at } \\
\text { home } \\
\text { Sweden }\end{array}$ & $\begin{array}{l}\text { Repeated individual interviews and } \\
\text { observations (for } 3 \text { weeks) were performed. } \\
\text { Two to } 4 \text { sessions of interviews and } \\
\text { observations per person, each session lasting } \\
\text { between } 1 \text { and } 2 \mathrm{~h} \\
\text { Data were analyzed using a phenomenological, } \\
\text { hermeneutical approach }\end{array}$ \\
\hline $\begin{array}{l}\text { Pipon-Young } \\
\text { et al. [71] }\end{array}$ & $\begin{array}{l}\text { To explore the experiences of younger } \\
\text { people with dementia and develop an } \\
\text { understanding of helpful support } \\
\text { To identify areas of the service in need for } \\
\text { change }\end{array}$ & $\begin{array}{l}N=8 \text { persons with dementia living at } \\
\text { home } \\
\text { UK }\end{array}$ & $\begin{array}{l}\text { Action research across } 3 \text { phases; semi- } \\
\text { structured individual interviews and field notes } \\
\text { were used } \\
\text { Data were analyzed using action research; } \\
\text { interpretative approach including thematic } \\
\text { analysis techniques in line with Charmaz and } \\
\text { concept mapping in accord with McNiff and } \\
\text { Whitehead }\end{array}$ \\
\hline $\begin{array}{l}\text { Rostad } \\
\text { et al. [73] }\end{array}$ & $\begin{array}{l}\text { To gain understanding of the lived } \\
\text { experience of younger people with dementia } \\
\text { ( }<65 \text { years) who lived at home and suffered } \\
\text { with early onset, and the meaning that could } \\
\text { be found in their experiences }\end{array}$ & $\begin{array}{l}N=4 \text { persons with dementia living at } \\
\text { home } \\
\text { Norway }\end{array}$ & $\begin{array}{l}\text { Individual, narrative individual interviews in a } \\
\text { conversational style with broad open-ended } \\
\text { questions were used } \\
\text { Phenomenological hermeneutic approach to } \\
\text { the analysis in line with Lindseth and Nordberg }\end{array}$ \\
\hline Sharp [74] & $\begin{array}{l}\text { To describe how people with dementia } \\
\text { perceive their experiences of stress and how } \\
\text { people with dementia cope with the stress } \\
\text { they experience }\end{array}$ & $\begin{array}{l}N=21 \text { persons with dementia living at } \\
\text { home } \\
\text { AD (13), vascular dementia (7), and } \\
\text { mixed (1) } \\
\text { Mean age: } 65.9 \\
\text { Women: } 52.3 \% \\
\text { Living with someone: } 66.7 \% \\
\text { UK }\end{array}$ & $\begin{array}{l}\text { Five focus group interviews } \\
\text { The authors used an interpretive } \\
\text { phenomenological analysis approach }\end{array}$ \\
\hline
\end{tabular}


Table 3 (continued)

\begin{tabular}{|c|c|c|c|}
\hline Authors [ref.] & Aim & Participants & Method \\
\hline $\begin{array}{l}\text { Sinclair } \\
\text { et al. [75] }\end{array}$ & $\begin{array}{l}\text { The study aimed to understand the lived } \\
\text { experiences of couples in which } 1 \text { partner is } \\
\text { diagnosed with dementia, in healthcare, } \\
\text { lifestyle, and everyday decision-making }\end{array}$ & $\begin{array}{l}N=13 \text { persons with dementia } \\
N=15 \text { spouse partners } \\
\text { Australia }\end{array}$ & $\begin{array}{l}\text { Dyadic interviews were conducted } \\
\text { The methodological approach was } \\
\text { interpretative phenomenological analysis }\end{array}$ \\
\hline $\begin{array}{l}\text { Sinclair } \\
\text { et al. [76] }\end{array}$ & $\begin{array}{l}\text { To understand the experiences of people } \\
\text { with dementia and their family members } \\
\text { with respect to decision-making and their } \\
\text { views on supported decision-making }\end{array}$ & $\begin{array}{l}N=25 \text { persons with dementia } \\
N=32 \text { participating family members } \\
\text { Australia }\end{array}$ & $\begin{array}{l}\text { Semi-structured dyadic interviews } \\
\text { The methodological approach was } \\
\text { interpretative phenomenological analysis }\end{array}$ \\
\hline $\begin{array}{l}\text { Stevenson } \\
\text { et al. [77] }\end{array}$ & $\begin{array}{l}\text { To explore concepts of risk and experiences } \\
\text { from the perspectives of individuals with } \\
\text { dementia and how risks were communicated } \\
\text { between these individuals with families and } \\
\text { healthcare providers }\end{array}$ & $\begin{array}{l}N=17 \text { persons with dementia } \\
\text { Women: } N=8 \\
\text { Northern Ireland }\end{array}$ & $\begin{array}{l}\text { Qualitative interviews were carried out } \\
\text { Data was analyzed using grounded theory }\end{array}$ \\
\hline $\begin{array}{l}\text { Tolhurst and } \\
\text { Weicht [79] }\end{array}$ & $\begin{array}{l}\text { Explore how men with dementia seek to } \\
\text { preserve their own personhood in response } \\
\text { to the impacts of the condition. Explore how } \\
\text { men with dementia seek to preserve their } \\
\text { own personhood in response to the impacts } \\
\text { of the condition. The authors claim that } \\
\text { there is a lack of a masculine-gendered } \\
\text { portrayal of the experience of dementia }\end{array}$ & $\begin{array}{l}N=14 \text { men with dementia and their } \\
\text { spouse, living at home } \\
\text { Mild-to-moderate AD (12), mild Levy } \\
\text { body (1), and moderate vascular } \\
\text { dementia (1) } \\
\text { Mean age: } 73.5 \text { (range } 58-89 \text { ) } \\
\text { UK }\end{array}$ & $\begin{array}{l}\text { Two semi-structured dyad interviews of all } 14 \\
\text { couples, with } 6 \text { months between each interview, } \\
\text { were conducted } \\
\text { Narrative analysis were conducted according to } \\
\text { Riessman }\end{array}$ \\
\hline $\begin{array}{l}\text { Van Vliet } \\
\text { et al. [80] }\end{array}$ & $\begin{array}{l}\text { Explore how people with YOD shape their } \\
\text { daily lives to retain a sense of usefulness }\end{array}$ & $\begin{array}{l}N=18 \text { persons with dementia living } \\
\text { at home, and } 21 \text { informal care givers } \\
\text { AD (8), frontotemporal (3) vascular } \\
\text { dementia (1), mixed (1), and not } \\
\text { specified }(n=5) \\
\text { Mean age: } 63.5 \text { (range } 57-70) \\
\text { Women: } 38.9 \% \\
\text { Living with someone: } 75 \% \\
\text { The Netherlands }\end{array}$ & $\begin{array}{l}\text { Focus groups, using a discussion guide with } \\
\text { open-ended questions } \\
\text { Qualitative content analysis in line with } \\
\text { Graneheim and Lundman and Elo and Kyngas } \\
\text { The analysis was supported by the software } \\
\text { Atlas.ti }\end{array}$ \\
\hline $\begin{array}{l}\text { Willis } \\
\text { et al. [82] }\end{array}$ & $\begin{array}{l}\text { To explore respondents' experiences with } \\
\text { help-seeking, understanding of dementia, } \\
\text { experiences with stigma, and the role of } \\
\text { religion among people with dementia in } \\
\text { Pakistan }\end{array}$ & $\begin{array}{l}N=20 \text { persons with dementia } \\
\text { Women: } n=9 \\
\text { Pakistan }\end{array}$ & $\begin{array}{l}\text { Semi-structured interviews. Carers were } \\
\text { present during the interviews } \\
\text { Thematic analysis was carried out drawing on a } \\
\text { pragmatic paradigm }\end{array}$ \\
\hline $\begin{array}{l}\text { Wolverson } \\
\text { et al. [83] }\end{array}$ & $\begin{array}{l}\text { To investigate the subjective experience of } \\
\text { hope of people with dementia }\end{array}$ & $\begin{array}{l}N=10 \text { persons with AD living at home } \\
\text { UK }\end{array}$ & $\begin{array}{l}\text { Individual semi-structured interviews with } \\
\text { open-ended questions were performed } \\
\text { Data were analyzed using interpretative } \\
\text { phenomenological approach in line with Smith }\end{array}$ \\
\hline $\begin{array}{l}\text { Öhman and } \\
\text { Nygård [84] }\end{array}$ & $\begin{array}{l}\text { To uncover and describe the meaning and } \\
\text { motives for engagement in self-chosen daily } \\
\text { life occupation for elderly individuals with } \\
\text { AD dwelling in community }\end{array}$ & $\begin{array}{l}N=6 \text { community-dwelling diagnosed } \\
\text { with AD. } \\
\text { Sweden }\end{array}$ & $\begin{array}{l}\text { Repeated individual interviews and } \\
\text { observations. Totally } 2 \text { or } 3 \text { times per person } \\
\text { A qualitative comparative analysis method was } \\
\text { used in accord with Bogdan and Biklen }\end{array}$ \\
\hline
\end{tabular}




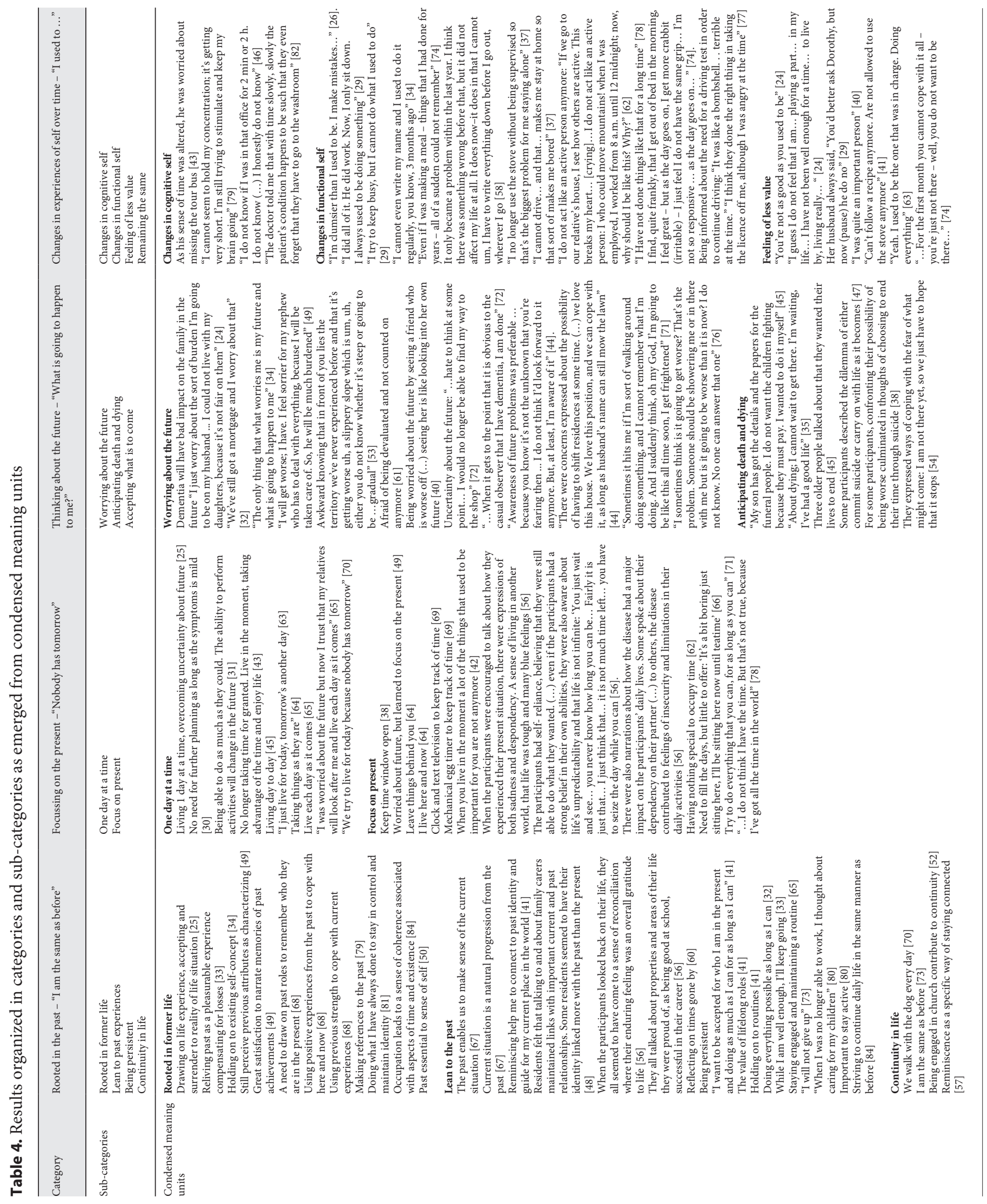




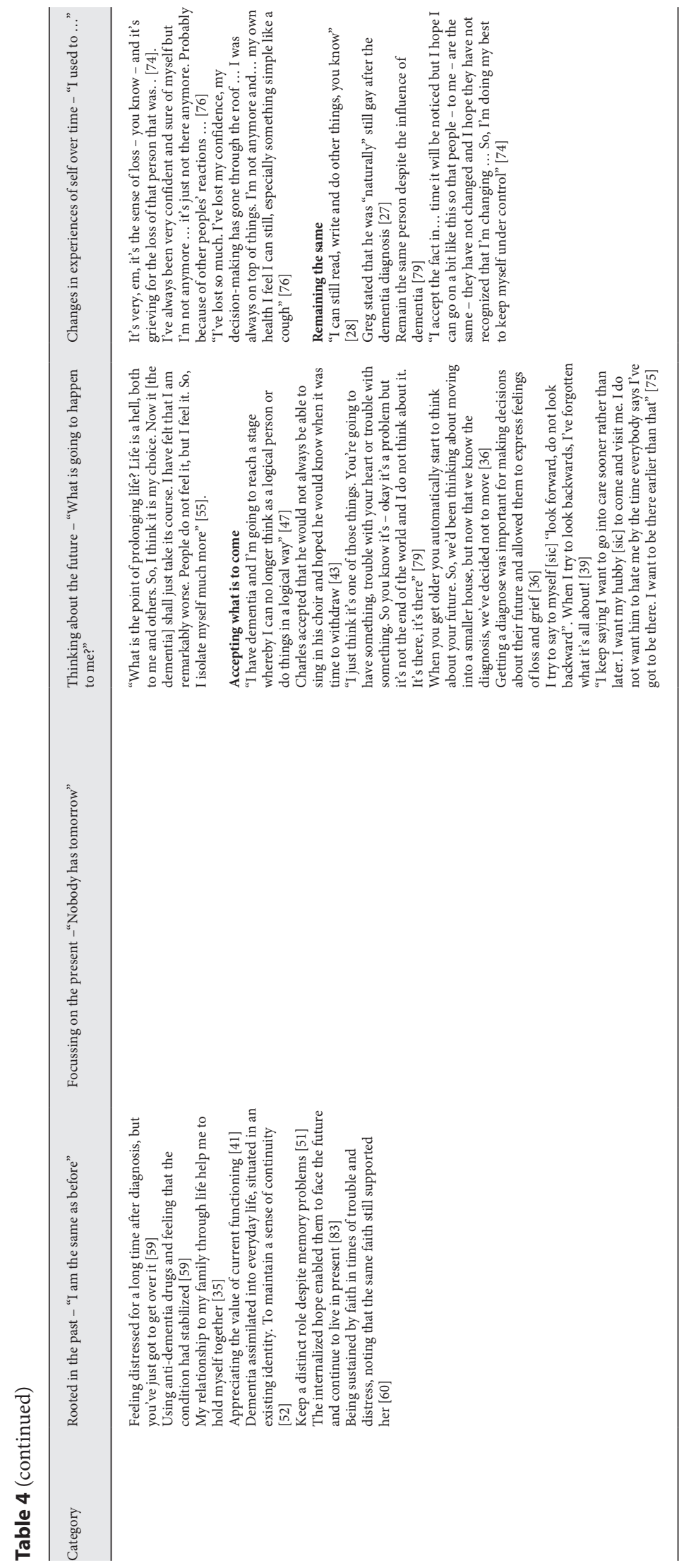


for losses, as one participant says, "I've faced quite a few challenges in my 90 years. So, I'm not letting this bother me. I think one just has to assume that everything's going to go well, and it probably will go well...I'll survive. I always have" [25]. Looking back helps individuals to cope with the here and now. They have managed their lives in the past, so they trust that they are able to manage and cope with their ongoing lives as well. The experience of themselves as the one they have been also seems to confirm their self-identity at present, as one participant says, "I am the same as before" [73]. Another participant states, "You must cling on to who you are" [34] which indicates that the past becomes an important source of identity. Narrating memories of achievements gives satisfaction and highlights positive aspects of life. Moreover, leaning on positive experiences from childhood and previous roles and statuses serves as a reminder of identity and can help a person to feel in control, as one participant says, "Doing what I have always done helps with staying in control of the situation and maintaining identity" [81].

Everyday occupation seems to lead to a sense of coherence associated with aspects of time and existence for people living with dementia. A person wants to be accepted in terms of their changing abilities and for who they were in the past. One participant says, "People should be allowing us to do as much as we can for as long as we can to the best of our present abilities" [41]. For many participants, the need to be persistent in their effort to keep going is illustrated in the following quotations: "I try to do everything possible, as long as I possibly can" [30] and "I'll still be energetic and not give up... I am not going to just sit down" [73]. Several participants mention the importance of staying engaged and look for new meaning in familiar routines such as walking the dog, exercising, or caring for the family. Some participants are grateful to have their current abilities, as illustrated in the following quotation: "Anything I can still do and function with I appreciate the value of far more than I did before" [41].

Life continuity, as in being the same person as before the diagnosis, is important. Holding on to religious activities and to reminisce familiar and mutual memories are the ways to keep connected with the past. One participant explains how engagement with the church contributes to a picture of continuity in the lives of people living with dementia, in which purpose and activity can remain, even alongside the challenges that the condition can create [52]. The internalized hope, embedded from childhood, enables people with dementia to live in present and face the future. Rooting themselves in the past helps to maintain personhood.

The Experience of Lived Time in People with Dementia
Focussing on the Present - "Nobody Has Tomorrow"

By focussing on the present, people with dementia can simultaneously leave the past behind and avoid thinking about the future. Living with a progressive, terminal disease enhances the need to live in the moment as one's future no longer is certain. One participant says, "We are just trying to live through the present day and for all good things that we have today because nobody has tomorrow. That is my motto now. We all have only today" [70]. Many of the articles reveal that participants prefer to focus on the present. Some feel that there is no need to plan ahead, as long as the situation is stable; take, for example, these participant comments: "We take it as it comes and we make the best of it" [30] and "Well I just live for today ... I just think we can put it right, tomorrow's another day ... I only know today at the moment. I have not a clue about tomorrow ... I do not get down about it ... I do not worry about it" [63]. Clearly, it is important for some people with dementia to focus on the present.

Living in the present seems to be a way of coping with uncertainties about the future. Some participants speak about how they used to feel terrified and have nightmares about the future but feel calmer now that they have learned to focus on the present. Others find relief in trusting family members to take good care of them as the condition progresses as illustrated by one participant who says, "I found that it is no use worrying, as I believe my sister and my children will look after me even at the worst stage. For now, I only wish I can continue to live each day as it comes" [65]. Also, delaying telling people about the diagnosis is a way of putting one's problems on hold. One participant shares his reflections about being open about his dementia diagnosis: "I thought there is no point in saying anything until... later on is in plenty of time, there is no point in worrying them all starting now you know" [88]. This illustrates that even though they are aware of the future and what might happen then, they choose to live "here and now."

Focussing on the present involves keeping track of clock time using memory aids such as books, calendars, digital clocks, text television, or in one case, a mechanical egg timer [69]. For some people with dementia, the everyday life can feel tedious, as illustrated in the following quotations: "It's a bit boring just sitting here, I'll be sitting here now until tea time" [66] and "I sit a lot and wait, but I do not know what I'm waiting for" [73]. Waiting for things to happen seems to be a common experience for participants in many of the studies.

Dement Geriatr Cogn Disord 2020;49:435-455 DOI: $10.1159 / 000511225$ 
Thinking about the Future - "What Is Going to

Happen to Me?"

Some people with dementia spend time thinking about the future. They perceive the future as a time of uncertainty and inevitable demise as one says, "It is going to get worse, that's the problem" [76]. For another participant, it is her sole concern, as she says; "The only thing that what worries me is my future and what is going to happen to me" [34]. Other participants express more specific concerns about the future, such as money, being a burden to their family, and their changing health status and care needs. For example, one participant says, "We always had plenty of money, then suddenly we had no money and you start thinking about the future" [32]. Another participant worries about how much help she will need from her spouse. She says, "I just worry about the sort of burden I'm going to be on my husband" [24]. Other participants are fearful of the future because they imagine that they will be forgetful all the time. They say, "I cannot remember what I am doing and, in the future, I'm going to be like this all the time. It is frightening." For another participant, such demise marks the end, saying, "When it gets to the point that it is obvious to the casual observer that I have dementia, I am done" [72]. These data highlight how people's experiences of dementia are sometimes orientated towards the future.

Thinking about the future means thinking about one's own deterioration and death. For some participants, this means taking practical steps in an attempt to either stop time or plan for the future. For example, participants in one study say that they take medication to hold back future time [38]. Others speak about making a will or planning their funeral. For example, one person says, "My son has got the details and the papers for the funeral. I do not want the children fighting because they must pay. I wanted to do it myself" [45]. Other participants think about their future in an existential way; one participant says, "What is the point of prolonging life? Life is a hell both for me and for others" [55]. Participants in 3 other studies report that they have had thoughts about suicide because they feared what was coming [38, 45, 47]. For one participant in her 90s, who believes in heaven, death cannot come soon enough; she says, "I cannot wait to get there. I'm waiting, I've had a good life" [35].

Some participants think more sanguinely about the future or they choose not to think about it all. They are inclined to accept the situation and to remain hopeful. For example, one person says, "I just think it's one of those things ... okay it's a problem but it's not the end of the world and I do not think about it" [79]. Participants in another study report that they tackle life with dementia by maintaining positive attitude towards their present and future [43]. One participant says, "I keep saying I want to go into care sooner rather than later" [75]. Other participants said that they told themselves, "Look forward, do not look backward" [39]. In these instances, thinking about the future is a positive orientation.

Changes in Experiences of Self over Time - "I Used to ..."

People with dementia notice changes in their experiences of self over time. The phrase "used to" features a lot in the data as participants describe how their character has altered over time due to the dementia by losing track of time [46] or forgetting what to do [82]. For example, in one study, a woman says, "I used to be a hard-working person, but it's all changed. I'm no longer interested in doing anything" [70]. Another person says, "I used to be very efficient, very ... exact. I knew exactly what I was doing" [41], and another remarks, "As a person, I always used to be in charge of what we were doing and everything ... but I could not do it now ... it's terrible" [63]. Others feel that they are no longer as useful or worthy as they used to be, as one participant says, "You're not as good as you used to be" [24] and another reflects, "I used to be one of the top medical professionals with executive responsibilities and was quite an important person" [40]. Some participants speak with frustration about how their current self is fundamentally different to their former working self, as one participant says, "I do not act like an active person anymore. When I was employed, I worked from 8 a.m. until 12 midnight; not now, why should I be like this? Why?" [62]. Some participants experience these shifts in self as a loss. One person says, "Everything is gone. I have lost those times (past life)" [64]. These data show how acutely some people with dementia experience changes in themselves over time.

Many people report functional changes and a significant difference in their everyday routines and priorities over a certain period. This is often due to changes in cognitive self. For example, one participant who likes to do crosswords and competitions in a weekly magazine for "brainwork" has noticed how much longer it is taking him to do them. He says, "6 months ago, I'd go through it in 2 days. It's taking me 7 days now" [79]. Another participant says, "I cannot even write my name and I used to do it regularly, you know, 3 months ago" [34]. Some others have noticed a change in their abilities in a relatively short space of time. They say, "It only became a problem within the last year. I think there was something wrong before that, but it did not affect my life" [58]. Changes in 
perceptions of self over time mean that some people are no longer being able to do practical things for themselves at home anymore, such as getting dressed [50], following a recipe [41], and using the stove [37]. One participant is frustrated about the need for a driving test to continue driving: "It was like a bombshell ... terrible at the time" [77]. Some others changed their shopping routine due to changes in how they feel when they are out; they say, "I am more stressed when I go shopping, so I go to the shop early in the morning" [31].

Not all participants experience a change in themselves; some feel that some things are still the same or that any changes are caused by their advancing age rather than dementia. One participant makes this reflection: "I do not think I have changed, I'm just the same. I would not drive as far as I use to, but I do drive. I do perhaps get a little bit anxious... It's all right, I am getting older anyway" [29]. Similarly, another participant says, "I can still read, write, and do other things, you know" [28]. In another study, a participant states that he "naturally" is still gay after the dementia diagnosis [27]. These are important data as they show how some people believe that they "remain the same person despite the influence of dementia" [79]. One participant tries to keep in control: "I hope they have not recognized that I'm changing ... so, I'm doing my best to keep myself under control" [74]. Overall, the analysis indicates that a change in the experience of self over time is common for people with dementia.

\section{Overall Theme}

An overall synthesis of the categories generated from the included articles reveals the comprehensive understanding, and the latent meaning is expressed as "being engaged with the dimensions of time." Together, the 4 categories, (1) rooted in the past - "I am the same as before"; (2) focussing on the present - "Nobody has tomorrow"; (3) thinking about the future - "What is going to happen to me?"; and (4) changes in the experience of self over time - "I used to...," show that people with dementia experience changes in self related to all 3 dimensions of time, the past, present, and future. Thus, the experience of lived time is an active and important one, in terms of enabling people to process and manage the dementia journey.

\section{Discussion}

The aim of this study was to locate, interpret, and synthesize the experience of lived time for people with dementia. People with dementia, especially older people, are

The Experience of Lived Time in People with Dementia often assumed to live in the past, but our findings show that this is not the case. The main findings indicate an experience of being engaged with all the dimensions of time - the past, present, and future. According to van Manen [7], lived time is an integral part of the human experience, and it is important that we take time into account when seeking to understand a person's lifeworld. In doing so, we can generate deeper insights into the fundamental existential experiences of a person's life, including how they make sense of life and death.

Participants in the studies we reviewed make a deliberate effort to engage with the different dimensions of time. They are consciously engaged in what sociologists have called "time work," that is, endeavouring to construct one's own temporal experience [89]. For instance, consider the efforts participants in the included studies make to live in the present and to avoid talking about the future. They work on taking things " 1 day at the time," as people so often do when faced with unexpected life course transitions [90]. In this sense, the dynamic of time influences how people with dementia process and manage the condition.

Sometimes people liked to root themselves in the past to help maintain their personhood. This confirms what other researchers have found that time and personhood are inevitably intertwined for people with dementia [91]. According to Flaherty, "time work functions as a temporal lathe with which to modify the contour of one's personal experience" [89]. It involves agency and self-determination and attributes that people with dementia are not always seen as having, but which become apparent when analyzing the subjective experience of time.

As shown in this study and others, people with dementia are capable of evolving into new and different selves over time [18]. Following a diagnosis, people with dementia can and do incorporate a "manageable disability identity" into their existing identities [17]. However, as the findings of this study indicate, the lived experience of this process is not necessarily an easy or comfortable one. Thinking about the future, and what might happen, and reflecting on how one used to be can be incredibly difficult for someone with a life-limiting, neurological condition such as dementia. Hence, people often choose to engage with the present (rather than the past or future). In this regard, people with dementia can remind us of the value of living in the moment and "slowing time down."

Research within the field of critical disability studies has emphasized the importance of understanding lived time from the perspective of those living with impairment and disability. By focussing on the temporal aspects of life 
with dementia, as we have done in this study, important questions are raised about how temporal norms (such as valuing speed) may be adversely affecting the lives of people with dementia, for example, Are people with dementia disadvantaged by temporal norms around communication in the same way as people with a speech impairment associated with other disabilities reportedly are? [92]. Our findings would suggest that they are, as whenever people engage with the dimensions of time, they often do so in relation to perceived temporal norms. Thus, experiences of lived time can be an indicator of social exclusion. The experience of lived time can be seen in relation to the neurological concept of "mental time travel," which refers to our cognitive ability as human beings to travel back into the past in our minds or imagine ourselves in the future. A temporal agentic practice is often overlooked by care providers as well as researchers in the field of dementia studies. Yet, as our study shows, people with dementia are engaged with the dimensions of time for much of their daily lives. As van Manen [7] argues, lived time is a key structure in our lives, no less so for people with dementia.

Our study has implications for dementia care practice and research. In practice terms, family and healthcare providers must be aware of their important role in improving people with dementia's lived experience of time not only in terms of time aids, such as speaking clocks, but also, and perhaps more critically, by making time a more explicit framework for intervention work. Dementia care practices are either past-orientated (e.g., reminiscence therapy and life history work), presentorientated (e.g., time aids and living in the moment), or future-orientated (e.g., advanced care planning and rehabilitation). Given the findings of this study, each one is vital for improving people with dementia's lived experience of time.

Research wise, our meta-synthesis has the potential to inform future scholarly work on time ethics - a construct developed by Norwegian researchers in relation to people with dementia in care home [12]. Time ethics denote a flexible time culture and carers working to a "sovereign time rhythm," that is, providing care in a way that they themselves define as good, rather according to the clock or using time as a stressor [12]. Our study brings to the fore people with dementia's lived experience of time, which is critical from an ethical perspective, as we need to know how people with dementia experience and are affected by time culture. Note, however, that we had to extract the data on time: none of the included studies set out to investigate peoples' temporal experiences. Thus, future work on improving the health and wellbeing of people with dementia in support situations should foreground the experience of lived time and time ethics.

\section{Strengths and Limitations}

The main strengths of this meta-synthesis are that (1) by combining studies, we have investigated the lived experience of time among a relatively large cohort of people with dementia and (2) it only included interviewbased studies involving people with dementia. The limitations are that the experiences of people with more advanced dementia are excluded and the lack of information in reviewed studies on the experiences of men and women with dementia from black and minority ethnic communities. Furthermore, we recognized that informants in interview-based studies are individuals who are willing and able to talk about their condition. Given these limitations, it is not possible to extrapolate findings to the entire dementia population.

\section{Acknowledgements}

The authors would like to thank university librarians Marit Gjone Sandsleth (University of South-East Norway) and Katarina Einarsen Enne and Vigdis Knutsen (Norwegian National Advisory Unit on Ageing and Health) for providing essential help and advice for the computer-aided search.

\section{Statement of Ethics}

Ethical approval and consent to participate have been gathered from the researchers responsible for each single study included in this meta-synthesis. As this is a literature review, ethical approval and consent to participate were not applicable.

\section{Conflict of Interest Statement}

The authors declare that they have no conflicts of interest.

\section{Funding Sources}

The study, including systematic literature search, assessment of the quality of the studies, analysis and interpretation of data, and writing the manuscript, was funded by the Norwegian Directorate of Health. However, the funding organization has not been involved in design, conducting the study, or interpretation of results. 


\section{Author Contributions}

All authors took part in the critical review and analysis of the data. T.L.I., E.K.G., and S.E. read all articles in full text. E.W.T., E.K.G., and S.E. made the quality assessment. A.M.M.R. and S.E. made condensation of meaning units. A.M.M.R., R.L.B., E.K.G., and S.E. further organized the meaning units into groups of categories and identified similarities and differences to make a structure of the codes into subcategories and categories. The categories were discussed by all the authors. S.E., R.L.B., E.K.G., and A.M.M.R. wrote the article in cooperation with the other authors. All authors have read and approved the final manuscript.

\section{References}

1 Jowsey T, Dennis S, Yen L, Mofizul Islam M, Parkinson A, Dawda P. Time to manage: patient strategies for coping with an absence of care coordination and continuity. Sociol Health Illn. 2016;38(6):854-73.

2 Mueller C, Soysal P, Rongve A, Isik AT, Thompson T, Maggi S, et al. Survival time and differences between dementia with Lewy bodies and Alzheimer's disease following diagnosis: a meta-analysis of longitudinal studies. Ageing Res Rev. 2019;50:72-80.

3 Husain M, Schott JM. Oxford textbook of cognitive neurology and dementia. Oxford: Oxford University Press; 2016.

4 Kitwood T. The experience of dementia. Aging Ment Health. 1997;1(1):13-22.

5 Adams B. Time and social theory. Cambridge: Polity Press; 1990.

6 Hawkins J. Well-being, time, and dementia. Ethics. 2014;124(3):507-42.

7 Van Manen M. Researching lived experience: human science for an action sensitive pedagogy. 2nd ed. London and New York: Routledge Taylor \& Francis Group; 2016.

8 Bevir M. Encyclopedia of political theory. University of California. Berkeley: SAGE Publications; 2010.

9 Dalla Barba G, La Corte V. The hippocampus, a time machine that makes errors. Trends Cogn Sci. 2013;17(3):102-4.

10 Topo P, Saarikalle K, Begley E, Cahill S, Holthe T, Macijauskiene J. "I don't know about the past or the future, but today it's Friday": evaluation of a time aid for people with dementia. Technol Disabil. 2007;19(2-3):12131.

11 D'Astous V, Abrams R, Vandrevala T, Samsi $\mathrm{K}$, Manthorpe J. Gaps in understanding the experiences of homecare workers providing care for people with dementia up to the end of life: a systematic review. Dementia. 2019; 18(3):970-89.

12 Egede-Nissen V, Jakobsen R, Sellevold GS, Sørlie V. Time ethics for persons with dementia in care homes. Nurs Ethics. 2013;20(1): 51-60.

13 Roach P, Drummond N. 'It's nice to have something to do': early-onset dementia and maintaining purposeful activity. J Psychiatr Ment Health Nurs. 2014;21(10):889-95.

14 Nygård L, Johansson $M$. The experience and management of temporality in five cases of dementia. Scand J Occup Ther. 2001;8(2):8595.

The Experience of Lived Time in People with Dementia
15 Marshall M, Gilliard J. Time for dementia. London: Hawker Publications; 2011.

16 Beard RL. Living with Alzheimer's: managing memory loss, identity and illness. New York: New York University Press; 2016.

17 Beard RL, Knauss J, Moyer D. Managing disability and enjoy life: how we reframe dementia trough personal narratives. J Aging Stud. 2009;23(4):227-35.

18 Tanner D. Identity, selfhood and dementia: messages for social work. Eur J Soc Work. 2013;16(2):155-70.

19 Droes RM, Chattat R, Diaz A, Gove D, Graff $\mathrm{M}$, Murphy K, et al. Social health and dementia: a European consensus on the operationalization of the concept and directions for research and practice. Aging Ment Health. 2017;21(1):4-17.

20 Eriksen S, Helvik AS, Juvet LK, Skovdahl K, Førsund LH, Grov EK. The experience of relations in persons with dementia: a systematic meta-synthesis. Dement Geriatr Cogn Disord. 2016;42(5-6):342-68.

21 Forsund LH, Grov EK, Helvik AS, Juvet LK, Skovdahl K, Eriksen S. The experience of lived space in persons with dementia: a systematic meta-synthesis. BMC Geriatr. 2018;18(1):33.

22 Shamseer L, Moher D, Clarke M, Ghersi D, Liberati A, Petticrew M, et al. Preferred reporting items for systematic review and metaanalysis protocols (PRISMA-P) 2015: elaboration and explanation. BMJ. 2015;350:g7647.

23 Critical Appraisal Skills Programme (CASP). Qualitative Research Checklist. Available from: http://www.casp-uk.net/2014.

24 Aldridge H, Fisher P, Laidlaw K. Experiences of shame for people with dementia: an interpretative phenomenological analysis. Dementia. 2019;18(5):1896-911.

25 Aminzadeh F, Dalziel WB, Molnar FJ, Garcia LJ. Symbolic meaning of relocation to a residential care facility for persons with dementia. Aging Ment Health. 2009;13(3):487-96.

26 Atta-Konadu E, Keller HH, Daly K. The foodrelated role shift experiences of spousal male care partners and their wives with dementia. J Aging Stud. 2011;25(3):305-15.

27 Barrett C, Crameri P, Lambourne S, Latham JR, Whyte C. Understanding the experiences and needs of lesbian, gay, bisexual and trans Australians living with dementia, and their partners. Australas J Ageing. 2015;34(Suppl 2):34-8.
28 Beattie A, Daker-White G, Gilliard J, Means R. 'How can they tell?' A qualitative study of the views of younger people about their dementia and dementia care services. Health Soc Care Community. 2004;12(4):359-68.

29 Borley G, Hardy S. A qualitative study on becoming cared for in Alzheimer's disease: the effects to women's sense of identity. Aging Ment Health. 2017;21(10):1017-22.

30 Bronner K, Perneczky R, McCabe R, Kurz A, Hamann J. Which medical and social decision topics are important after early diagnosis of Alzheimer's disease from the perspectives of people with Alzheimer's disease, spouses and professionals? BMC Res Notes. 2016;9: 149.

31 Brorsson A, Öhman A, Lundberg S, Nygård L. Accessibility in public space as perceived by people with Alzheimer's disease. Dementia. 2011;10(4):587-602.

32 Chaplin R, Davidson I. What are the experiences of people with dementia in employment? Dementia. 2016;15(2):147-61.

33 Clare L, Rowlands J, Bruce E, Surr C, Downs $M$. The experience of living with dementia in residential care: an interpretative phenomenological analysis. Gerontologist. 2008;48(6): 711-20.

34 Clemerson G, Walsh S, Isaac C. Towards living well with young onset dementia: an exploration of coping from the perspective of those diagnosed. Dementia. 2014;13(4):451-66.

35 Dalby P, Sperlinger DJ, Boddington S. The lived experience of spirituality and dementia in older people living with mild to moderate dementia. Dementia. 2012;11(1):75-94.

36 Derksen E, Vernooij-Dassen M, Gillissen F, Olde Rikkert M, Scheltens P. Impact of diagnostic disclosure in dementia on patients and carers: qualitative case series analysis. Aging Ment Health. 2006;10(5):525-31.

37 De Witt L, Ploeg J, Black M. Living on the threshold: the spatial experience of living with dementia. Dementia. 2009;8(2):263-91.

38 De Witt L, Ploeg J, Black M. Living alone with dementia: an interpretive phenomenological study with older women. J Adv Nurs. 2010; 66(8):1698-707.

39 Digby R, Moss C, Bloomer M. Transferring from an acute hospital and settling into a subacute facility: the experience of patients with dementia. Int J Older People Nurs. 2012;7(1): 57-64. 
40 Frazer SM, Oyebode JR, Cleary A. How older women who live alone with dementia make sense of their experiences: an interpretative phenomenological analysis. Dementia. 2011; 11(5):677-93.

41 Genoe R, Dupuis SL, Keller HH, Martin LS, Cassolato C, Edward HG. Honouring identity through mealtimes in families living with dementia. J Aging Stud. 2010;24(3):181-93.

42 Genoe MR, Keller HH, Martin LS, Dupuis SL, Reimer H, Cassolato C, et al. Adjusting to mealtime change within the context of dementia. Can J Aging. 2012;31(2):173-94.

43 Genoe MR, Dupuis SL. The role of leisure within the dementia context. Dementia. 2014; 13(1):33-58.

44 Gilmour JA, Huntington AD. Finding the balance: living with memory loss. Int J Nurs Pract. 2005;11(3):118-24.

45 Goodman C, Amador S, Elmore N, Machen I, Mathie E. Preferences and priorities for ongoing and end-of-life care: a qualitative study of older people with dementia resident in care homes. Int J Nurs Stud. 2013;50(12):1639-47.

46 Hagan RJ. What next? Experiences of social support and signposting after a diagnosis of dementia. Health Soc Care Community. 2020;28(4):1170-9.

47 Harman G, Clare L. Illness representations and lived experience in early-stage dementia. Qual Health Res. 2006;16(4):484-502.

48 Harmer BJ, Orrell M. What is meaningful activity for people with dementia living in care homes? A comparison of the views of older people with dementia, staff and family carers. Aging Ment Health. 2008;12(5):548-58.

49 Hedman R, Hansebo G, Ternestedt BM, Hellstrom I, Norberg A. How people with $\mathrm{Al}$ zheimer's disease express their sense of self: analysis using Rom Harre's theory of selfhood. Dementia. 2013;12(6):713-33.

50 Hedman R, Hansebo G, Ternestedt BM, Hellström I, Norberg A. Expressed sense of self by people with Alzheimer's disease in a support group interpreted in terms of agency and communion. J Appl Gerontol. 2016;35(4): $421-43$.

51 Hellstrom I, Eriksson H, Sandberg J. Chores and sense of self: gender understandings of voices of older married women with dementia. Int J Older People Nurs. 2015;10(2):12735.

52 Hillman A, Jones IR, Quinn C, SMN, M Nelis S. Dualities of dementia illness narratives and their role in a narrative economy. Sociol Health Illn. 2018;40(5):874-91.

53 Hulko W. From 'not a big deal' to 'hellish': experiences of older people with dementia. J Aging Stud. 2009;23(3):131-44.

54 Johannessen A, Möller A, Haugen PK, Biong S. A shifting sense of being: a secondary analysis and comparison of two qualitative studies on young-onset dementia. Int J Qual Stud Health Well-Being. 2014;9:24756.
55 Johannessen A, Engedal K, Haugen PK, Dourado MCN, Thorsen K. "To be, or not to be": experiencing deterioration among people with young-onset dementia living alone. Int $J$ Qual Stud Health Well-Being. 2018;13(1): 1490620.

56 Karlsson E, Sävenstedt S, Axelsson K, Zingmark K. Stories about life narrated by people with Alzheimer's disease. J Adv Nurs. 2014; 70(12):2791-9.

57 Keller HH, Schindel Martin L, Dupuis S, Genoe R, Gayle Edward H, Cassolato C. Mealtimes and being connected in the community-based dementia context. Dementia. 2010; 9(2):191-213

58 Langdon SA, Eagle A, Warner J. Making sense of dementia in the social world: a qualitative study. Soc Sci Med. 2007;64(4):989-1000.

59 Lee SM, Roen K, Thornton A. The psychological impact of a diagnosis of Alzheimer's disease. Dementia. 2014;13(3):289-305.

60 MacKinlay E. Using spiritual reminiscence with small group of Latvian residents with dementia in nursing home: a multifaith and multicultural perspective. J Relig Spiritual Aging. 2009;21(4):318-29.

61 MacRae H. Self and other: the importance of social interaction and social relationships in shaping the experience of early-stage $\mathrm{Al}$ zheimer's disease. J Aging Stud. 2011;25(4).

62 Mazaheri M, Eriksson LE, Heikkilä K, Nasrabadi AN, Ekman SL, Sunvisson H. Experiences of living with dementia: qualitative content analysis of semi-structured interviews. J Clin Nurs. 2013;22(21-22):3032-41.

63 Merrick K, Camic PM, O'Shaughnessy M. Couples constructing their experiences of dementia: a relational perspective. Dementia. 2016;15(1):34-50.

64 Mjorud M, Engedal K, Rosvik J, Kirkevold M. Living with dementia in a nursing home, as described by persons with dementia: a phenomenological hermeneutic study. BMC Health Serv Res. 2017;17(1):93.

65 Mok E, Lai CK, Wong FL, Wan P. Living with early-stage dementia: the perspective of older Chinese people. J Adv Nurs. 2007;59(6):591600.

66 Moyle W, Venturto L, Griffiths S, Grimbeek P, McAllister M, Oxlade D, et al. Factors influencing quality of life for people with dementia: a qualitative perspective. Aging Ment Health. 2011;15(8):970-7.

67 Molyneaux VJ, Butchard S, Simpson J, Murray $\mathrm{C}$. The co-construction of couplehood in dementia. Dementia. 2011;11(4):483-502.

68 Nowell ZC, Thornton A, Simpson J. The subjective experience of personhood in dementia care settings. Dementia. 2013;12(4):394-409.

69 Nygard L. Meaning of everyday technology as experienced by people with dementia who live alone. Dementia. 2008;7(4):481-502.

70 Pesonen HM, Remes AM, Isola A. Diagnosis of dementia as a turning point among Finnish families: a qualitative study. Nurs Health Sci. 2013;15(4):489-96.
71 Pipon-Young FE, Lee KM, Jones F, Guss R. I'm not all gone, I can still speak: the experiences of younger people with dementia. An action research study. Dementia. 2012;11(5): 597-616.

72 Read ST, Toye C, Wynaden D. Experiences and expectations of living with dementia: a qualitative study. Collegian. 2017;24(5):42732.

73 Rostad D, Hellzén O, Enmarker I. The meaning of being young with dementia and living at home. Nurs Rep. 2013;3(1):3-7.

74 Sharp BK. Stress as experienced by people with dementia: an interpretative phenomenological analysis. Dementia. 2019;18(4):142745.

75 Sinclair C, Gersbach K, Hogan M, Bucks RS, Auret KA, Clayton JM, et al. How couples with dementia experience healthcare, lifestyle, and everyday decision-making. Int Psychogeriatr. 2018;30(11):1639-47.

76 Sinclair C, Gersbach K, Hogan M, Blake M, Bucks R, Auret K, et al. "A real bucket of worms": views of people living with dementia and family members on supported decisionmaking. J Bioeth Inq. 2019;16(4):587-608.

77 Stevenson M, Savage B, Taylor BJ. Perception and communication of risk in decision making by persons with dementia. Dementia. 2019;18(3):1108-27.

78 Svanstrom R, Sundler AJ. Gradually losing one's foothold: a fragmented existence when living alone with dementia. Dementia. 2015; 14(2):145-63.

79 Tolhurst E, Weicht B. Preserving personhood: the strategies of men negotiating the experience of dementia. J Aging Stud. 2017; 40:29-35.

80 van Vliet D, Persoon A, Bakker C, Koopmans RTCM, de Vugt ME, Bielderman A, et al. Feeling useful and engaged in daily life: exploring the experiences of people with youngonset dementia. Int Psychogeriatr. 2017; 29(11):1889-98.

81 van Zadelhoff E, Verbeek H, Widdershoven G, van Rossum E, Abma T. Good care in group home living for people with dementia. Experiences of residents, family and nursing staff. J Clin Nurs. 2011;20(17-18):2490-500.

82 Willis R, Zaidi A, Balouch S, Farina N. Experiences of people with dementia in Pakistan: help-seeking, understanding, stigma, and religion. Gerontologist. 2020;60(1):145-54.

83 Wolverson EL, Clarke C, Moniz-Cook E. Remaining hopeful in early-stage dementia: a qualitative study. Aging \& Mental Health. 2010;14(4):450-60.

84 Öhman A, Nygård L. Meanings and motives for engagement in self-chosen daily life occupations among individuals with Alzheimer's disease. OTJR. 2005;25(3):89-97.

85 Dixon-Woods M, Agarwal S, Jones D, Young B, Sutton A. Synthesising qualitative and quantitative evidence: a review of possible methods. J Health Serv Res Policy. 2005;10(1): 45-53. 
86 Eilertsen G, Ormstad H, Kirkevold M. Experiences of poststroke fatigue: qualitative metasynthesis. J Adv Nurs. 2013;69(3):514-25.

87 Graneheim UH, Lundman B. Qualitative content analysis in nursing research: concepts, procedures and measures to achieve trustworthiness. Nurse Educ Today. 2004; 24(2):105-12
88 Weaks D, Wilkinson H, McLeod J. Daring to tell: the importance of telling others about a diagnosis of dementia. Aging Soc. 2015;35(4): 763-84.

89 Flaherty MG. Textures of time: agency and temporal experience. Philadelphia: Temple University Press; 2011.

90 Shirani F, Henwood K. Taking one day at a time: temporal experiences in the context of unexpected life course transitions. Time Soc. 2011;20(1):49-68.
91 Gjødsbøl IM, Svendsen MN. Time and personhood across early and late-stage dementia. Med Anthropol. 2019;38(1):44-58.

92 Paterson K. It's about time! Understanding the experience of speech impairment. In: Watson N, Vehmas S, editors. Handbook in disability studies. 2nd ed. London: Routledge; 2020. p. 206-18. 